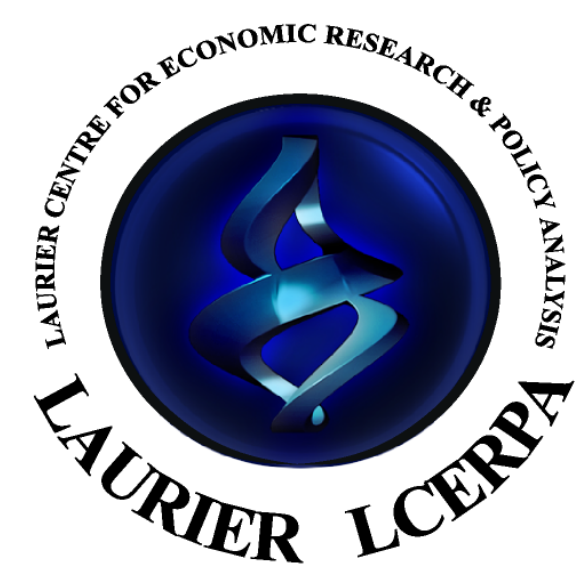

Economic Research Paper

\title{
Revisiting the Coyne Affair: A Singular Event that Changed the Course of Canadian Monetary History
}

\author{
Pierre L. Siklos*
}

August 2008

\begin{abstract}
* Professor of Economics, Department of Economics, School of Business and Economics, Wilfrid Laurier University, Waterloo, Ontario, Canada.

Jennifer Brickman and Garry Tang provided excellent research assistance. Richard Burdekin, Charles Goodhart, and David Laidler provided comments on an earlier draft. I am also grateful to Simon van Norden and Robert Rasche for their help in providing some of the real time data used in the paper. I also wish to thank Heather Ryckman and Jane Boyko of the Bank of Canada Archives for their assistance in providing documents from the Coyne era. An earlier version was presented at the International Economic History Association Conference, Helsinki, Finland..
\end{abstract}




\begin{abstract}
The Coyne Affair is the greatest institutional crisis faced by the Bank of Canada in its history. The crisis took place in 1959-1961 and led to the resignation of the Governor, once he was cleared of any wrongdoing. The crisis eventually resulted in a major reform of the Bank of Canada Act. Archival and empirical evidence is used to assess the performance of monetary policy throughout the 1950s. In doing so, a real-time dataset is constructed for both Canada and the US that permit estimation of reaction functions. I find that the case against James Coyne is 'not proven'.
\end{abstract}

Pierre L. Siklos, Wilfrid Laurier University

e-mail:psiklos@wlu.ca

Home Page: www.wlu.ca/sbe/psiklos

Phone: (519) 884-0710, ext. 2491

Fax: (519) 884-5922

JEL Classification Codes: N100, E52, E58, C52

Keywords: Coyne Affair, monetary policy stance, Taylor rules, real-time data. 


\section{Introduction}

The Coyne Affair arguably represents the greatest institutional crisis ever faced by the Bank of Canada. The conflict between the then Governor, James E. Coyne, and the Conservative government led by Prime Minister John Diefenbaker, took place less than 25 years into the Bank’s existence. In spite of warnings from academics and policymakers that the responsibilities of the Bank of Canada were poorly defined, the prevailing view was that “if it ain't broke, don't fix it.” Adding to the tension was the fact that, virtually alone in the industrial world, Canada chose to return to a floating exchange rate precisely because policymakers firmly believed that an independent monetary policy was in the nation's best interests. ${ }^{1}$ Having done so, officials in government lost sight of the fact that the position of a central bank under a float matters whereas, under a fixed exchange rate regime, the central bank can no longer be independent, in this case from US monetary policy.

Arguably, a conflict between the government and the central bank was perhaps inevitable, even if observers at the time were somewhat dismissive of the likelihood of such an occurrence. Having opted for a made-in-Canada monetary policy, the Bank allowed the stance of monetary policy to be dictated by the behavior of short-term interest rates. This may have been a first in the industrial world. In retrospect, inexperience with this type of monetary policy strategy, combined with a peculiar communications policy, created a 'perfect storm' that erupted as the decade of the 1950s ended. While the story of the Coyne Affair is partly one of a clash of personalities between the Governor and the Minister of Finance, Donald Fleming, this paper tries to eschew this angle and focuses instead on how monetary policy was carried out and explained in public. The paper also alludes to the academic debate that raged in Canada at the time. The resulting debate was not relegated only to scholarly journals but, perhaps unusually, it was also played out in public.

Drawing on material from the Bank of Canada’s Archives, as well as other sources, I revisit the conduct of monetary policy in Canada during the 1950s. In essence, this paper represents a case study of the political economy of monetary policy. Nevertheless, the lessons

\footnotetext{
${ }^{1}$ Mittra (1977) offers an historical account of select conflicts between the Treasury and the central bank, including the one between Coyne and the Government. It is easy to fall into the trap of believing that there was inadequate understanding of how monetary policy might function under a floating exchange rate regime. Between 1914 and 1939, for example, Canada's exchange rate was flexible and policymakers during the late 1940 and early 1950 s felt that, overall, the experience was a good one. See, for example, Siklos (2008), Powell (1999), and Cornell (19521955).
} 
learned have broader implications for the role of central bank transparency and accountability, and the importance of matching institutional design with the requirements of the monetary policy regime the central bank is expected to function under.

The paper is structured as follows. The next section describes the general economic environment Canada's monetary policy operated under from the mid-1950s until shortly after Coyne resigned. Section 3 outlines how the Coyne affair actually erupted. While the conflict ostensibly centered on Coyne's pension, it was not long before his stewardship of monetary policy was being questioned by politicians and academics alike. Section 4 presents some evidence based on an assessment of the stance of monetary policy using some newly constructed real time data for the 1950s. Specifically, I ask whether the Bank tightened monetary policy excessively based on estimates of instrument rules. Section 5 concludes by suggesting that while monetary policy was overly tight for a short period of time (essentially 2 quarters), the Bank quickly reversed course and loosened policy. Ultimately, the Coyne affair was also about the institutional independence of the Bank of Canada. Coyne may have seemingly lost the battle when he resigned but his successor, Louis Rasminsky, won the war.

\section{Monetary Policy at the Bank of Canada, 1954-61}

As the 1950s began there was tremendous optimism about the role and potential importance of monetary policy, in both the U.S. and in Canada. Arthur Burns, who would become Chair of the FOMC during the 1970s, argued in 1954 that "the government must use monetary policy in a flexible manner and assign it a very high priority in the arsenal of contracyclical weapons" (as quoted in Bremner (2004), p. 110). Exuberance about the promise of monetary policy was also reflected in the popular press. The New York Times, citing Burns, commented that "If government policy proceeds on these premises, we will avoid in the future the depressions that have marred the brilliant record of free enterprise in the past” (as quoted in Bremner (2004), p. 110).

Figures 1 and 2 help set the stage for understanding the Bank of Canada's assessment about overall economic conditions and its changing views about the stance of monetary policy. A central element in the story of the Coyne Affair requires contrasting monetary policy in Canada vis-à-vis that of the U.S. Hence, comparable U.S. data are also plotted. As is clear from these figures, inflation and unemployment rates are remarkably similar in both countries over the period considered. Also shown in the bottom Figure are the shaded areas indicating NBER 
recession dates. While these are, strictly speaking, applicable to U.S. data only, as we shall see below, Bank of Canada commentary suggests that U.S. and Canadian business cycles were roughly in phase throughout much of the 1950s. Indeed, the striking similarities in US and Canadian business cycles in spite of a flexible exchange rate regime, is one of the puzzles that has yet to be fully explained. ${ }^{2}$

Turning to some indicators of monetary policy shown in Figure 2, we see rather dramatic differences between Fed and Bank of Canada interest rate policies. Following Goodfriend (1998), on short-term and long-term interest rate indicators can also be used to evaluate the stance and credibility of monetary policy in Canada. Changes in long-term interest rates are assumed to reflect changes in expectations of inflation. Sustained increases in long-term interest rates signal an "inflation scare”, a topic much discussed - using different language - in successive Bank of Canada Annual Reports to be discussed below. However, unlike the Fed, which responded to the threat of higher inflation in measured steps, and reversed course quickly once the inflation scare passed, ${ }^{3}$ the Bank of Canada responded aggressively both to larger and smaller increases in long-term rates in almost equal measure. Canadian short-term interest rates are considerably more volatile than in the US while the failure of long-term rates in Canada to fall after 1958, in spite of a fall in inflation, suggests perhaps a lack of credibility in monetary policy. In contrast, over the same period, long-term interest rates fell in the US. Figure 2, therefore, nicely encapsulates both the differences between U.S. and Canadian monetary policies, as well as hinting at a possible source for the brewing conflict between the federal government and the Bank of Canada.

An additional factor undoubtedly was Canada's decision to abandon the Bretton Woods system in late 1950 (Powell 1999, p. 61), a mere five years after the creation of the post-war exchange rate system. The Canadian dollar had previously been devalued from par with the U.S. dollar to $90.9 \$$ in 1949. The Bank feared that the currency was undervalued, partly as a result of a then secret memorandum prepared in 1949 by Coyne himself who advocated a moving peg “... which could move up or down from time to time as economic conditions might require” (Coyne

\footnotetext{
${ }^{2}$ See, for example, Bordo, Dib and Schembri (2007), and Siklos (2008), and references therein.

${ }^{3}$ An instructive account of the measured response of the US Fed during the first half of the 1950s especially, can be found in McChesney Martin (1957).
} 
1949). ${ }^{4}$ The rise in commodity prices combined to put upward pressure on the Canadian dollar assisted by strong inflows of capital. In a letter to then Governor Graham Towers the Minister of Finance, D.C. Abbott, informed the Bank of the government's decision “...not to maintain a fixed rate of exchange...” (Rasminsky 1946-1951). Figure 3 shows the evolution of the nominal exchange rate against the U.S. dollar before, during, and shortly after re-entry into the Bretton Woods arrangement in May 1962. The divergence between the official and free market exchange rates prior to 1950 is apparent and helps explain the attraction of liberating the exchange rate from its peg. Freed from the peg domestic monetary policy was able to set an independent course, a point well understood by policy makers. ${ }^{5}$ Nevertheless, while monetary conditions would continue to be assessed via developments in the money supply, James Coyne's accession to the Governorship would lead to the introduction of an interest rate instrument. There was also an understanding of the connection between exchange rate changes and inflation, on the one hand, and inflation and interest rates on the other. Indeed, Bank of Canada estimates of the passthrough effects during the 1950s suggest that a roughly 6\% change in the exchange rate led to a 1\% change in the CPI (Johnstone 1958). These features of the conduct of monetary policy were further underscored by the decision, beginning November 1956, to allow the bank rate to float with the three month yield in Treasury bills, by maintaining a one-quarter of one percent differential between the two instruments.

Not surprisingly, much of the controversy that would eventually culminate in the Coyne affair centers on whether the stance of monetary policy was appropriate as both the US and Canadian economies began to struggle during the second half of the 1950s. Figure 4 plots four different measures of the output gap, the modern equivalent of the capacity utilization concept that would have been referred to in descriptions of general economic developments in successive Annual Reports of the Bank of Canada. Other than perhaps the linear trend case (LT), the remaining proxies, namely the Blanchard-Quah (BQ) decomposition (see Blanchard and Quah

\footnotetext{
${ }^{4}$ Coyne also considered maintaining the peg but preferred a much wider fluctuation band than the $\pm 1 \%$ permitted under Bretton Woods. This plan was thought to be less desirable both because the current peg need not necessarily be an equilibrium one as well as because no one knew how wide the band ought to be. It is arguable whether Bretton Woods was fully in place prior to 1959, when current account convertibility was established in the industrial world. ${ }^{5}$ This is not a view shared by everyone. Bordo, Dib, and Schembri (2007) use counterfactual experiments to show that Canada's experience with floating rates in the 1950s was not an unqualified success. Siklos (2008) considers whether the puzzling stability of the Canadian dollar throughout much of the 1950s experiment with floating exchange rates was due to the intervention activities of the Bank of Canada which the literature generally thought was unimportant but turns out to have played a more significant role than previously believed.
} 
1989), the nowadays widely-used Hodrick-Prescott (HP) filter, and quadratic trend (QT) cases would not have been widely used, or known, in the 1950s. The lines labelled_RT refer to data that are based on the January 1972 vintage, while the lines labelled_FL in the bottom portion of Figure 4 refer to data based on the April 2003 vintage. ${ }^{6}$ It is apparent from both Figures that revisions can be substantial partly due to changing definitions of the variables of interest (e.g., from GNP or GNE to GDP, fixed-weights through chain-weights). Virtually all "real time” data reveal a boom from 1955 to 1957, with the exception of the BQ filter. The same boom is less evident based on the final data. Indeed, the linear trend shows excess capacity in the economy through the entire 1950s, except briefly in 1956. However, as pointed out above, even these data are considerably revised relative to those that policy makers, and academics, could have seen during the 1950s. To illustrate, Figure 5 plots output gaps based on the LT, QT, and HP filters for the 1957Q4 vintage. This roughly corresponds to the vintage of data that would have been used to prepare the Bank of Canada's 1957 Annual Report while the 1960Q2 vintage would describe economic activity around the time of Coyne's departure from the Bank. These data tell an altogether different story. The 1957 vintage is roughly similar to the quasi real time estimates shown in Figure 4 although the recession in 1954 would have appeared deeper to policy makers than if data revised and corrected by the early 1970s had been available to them. The same is true of the boom that was experienced in the early 1950s. By 1960, the picture looked different again, with the boom of 1956 considerably stronger than was apparent just three years earlier while the recession of 1958-59 was perhaps not as deep as might have appeared at first, depending on the chosen filter. Subsequent revisions (see Figure 5) would suggest a considerably deeper recession than was evident from the data at the time it would have been available to policy makers. What is perhaps most striking about all these figures, but especially from the data for the 1960Q2 vintage, are the large swings away from potential output. ${ }^{7}$

The Bank of Canada’s Annual Report was an important vehicle used by the central bank to explain its policy actions. According to the version of the Bank of Canada Act in force at the time (section 27; see Aufricht 1967, vol. 2), the Bank was only required to provide financial accounts. There was no requirement to include a discussion or an assessment of the conduct of

\footnotetext{
${ }^{6}$ The construction and sources for the 'real-time' data are detailed in section 4 below.

${ }^{7}$ Critics would not find much comfort in the behaviour of the US output gap. Based on the earliest vintage of data available (February 1966), the output gap is as large and as volatile as in the Canadian case (not shown), as well as being largely coincident. Data for the US is from the real time data base of the Federal Reserve Bank of Philadelphia (www.phi.frb.org/econ/forecast./reaindex.html).
} 
monetary policy. Coyne, however, began to rely on the Annual Reports as an important communications device.

As 1957 began inflation was the principal preoccupation of the Bank. At the same time, however, the 1957 Annual Report devotes considerable space to the limits of monetary policy. While recognizing that monetary policy ought to avoid conditions in which there are sharp spurts in inflation, the Report states that “..., the objective of monetary policy should be - and is - to encourage and assist an increase in economic activity” (Bank of Canada 1958, p. 23). Elsewhere, the Report suggests that, in spite of the “... added flexibility which a free exchange rate provides” (op. cit., p. 17-18), there are substantial limitations to the insulating properties of the exchange rate system. It is worth pointing out again that Coyne was one of the architects of the adoption of a floating exchange rate (Powell 1999, p. 62).

The 1958 Annual Report states the Bank’s objective in a rather different tone. Whereas the compatibility of price stability with economic growth is highlighted, the language is more precise. Coyne sees the Bank’s essential role as “... regulating the rate of change in overall monetary supply in such a manner as is consistent with and, so far as monetary actions can, will contribute to sound and sustained economic growth under stable prices” (Bank of Canada 1959, p. 9). The year 1958 is also significant as it marks the start of the Federal government's Conversion Loan Program when short-term wartime Victory Loan bonds were to be exchanged for longer-term government bonds. ${ }^{8}$ As always, economic developments in the United States loomed large and, once again, the Bank warned of the dangers of higher expectations of inflation. Nevertheless, the Governor labeled such fears as “exaggerated” (op. cit., p. 3).

The 1959 Annual Report (Bank of Canada 1960) sees a significant, if not dramatic, change in tone. The Report begins by quoting the Bank of Canada Act of 1934 to underline both the importance of stable prices and the inability of the central bank to shoulder the entire burden for economic management. "Above all, I am concerned ... in the thought that there is in monetary management some magical power or hidden hand which will relieve us of the necessity of remedying our situation by our own exertions, by not consuming more than we produce, and by prudent management of our collective affairs” (op. cit., p. 10).

\footnotetext{
8 The average maturity was thereby lengthened from 6 years and 2 months to 10 years and 7 months. See Bank of Canada (1959, p. 27).
} 
We read for the first time a warning by Governor Coyne over the deleterious consequences of government deficits and the negative economic consequences of “...excessive overall spending...” reflected in “...huge deficits in our international balance of payments on current accounts” (op. cit., p. 7). Several passages of the Annual Report hammer away at the potential for loose fiscal policy to threaten growth and stability in the Canadian economy.

The 1960 Annual Report represents a plea to the public to understand the limits of monetary policy. Written in 1959, when the recession in Canada was largely blamed on Bank of Canada policies, Coyne asserts that central banking is not about achieving price stability at the expense of economic growth. He goes over the heads of the politicians - by now what would eventually be called the Coyne Affair is in full swing - and pleads to the public that “...emphasis which is placed from time to time on the limitations of monetary management by those who are engaged in central banking is based on concern over the healthy vigor of the economy, it is not a sign of an uncooperative spirit or a desire to create difficulties” (Bank of Canada 1961, p. 23). Indeed, consistent with the spirit of the Bank of Canada Act, Coyne declares that the "...goals of full employment, sustained economic growth, stable prices, and a sound currency, must all be pursued simultaneously. It should not be necessary - were it not for rather extreme statements that have appeared in some public discussions of these matters - to remark that the Bank of Canada is not in any way opposed to the idea of full employment, and does not operate with a view to restricting economic growth or preventing increased employment in the supposed interests of monetary policy or of anti-inflation endeavours” (Bank of Canada 1961, p. 16).

In Coyne's view, culprits for the woes facing the Canadian economy are the current account deficit and insufficient investment (Bank of Canada 1961, pp. 14-15). He continues to blame inappropriate fiscal policy for making matters worse though the tone is far less bellicose than in the 1959 Annual Report.

One can surmise from the foregoing quotes that the Bank is under attack by the government over poor economic growth, high unemployment and interest rates. The Bank's reactions are unprecedented and rather unusual from the central banking perspective at the time. While Coyne was responsible for monetary policy in Canada before the full impact of Phillips' (1958) paper led some academics to begin thinking that economic management was a simple matter of picking the appropriate point on a Phillips curve, there were plenty of references in internal Bank of Canada memoranda that explicitly questioned whether any such trade-off 
existed. ${ }^{9}$ In contrast, nowadays, we live with an understanding of the inconsistency of optimal plans due to Kydland and Prescott (1977). The implications of the lack of formal central bank autonomy, combined with a sense that monetary policy cannot cure all economic ills, is most cogently reflected in Coyne’s day with the statement: “central bankers throughout the world have come to expect far too much of monetary manipulation both in counteracting strong inflationary forces and promoting sound economic growth and overcoming recession” (Bank of Canada 1961, p. 23). ${ }^{10}$

As novel as the Bank of Canada Annual Reports may have been in assisting policymakers and the public in understanding how monetary policy was being implemented, the Bank was not without its harsh critics. Gordon and Read (1958) is mainly a plea for greater transparency and clarity in the communication of monetary policy. The authors complain of the Bank's supposedly loose language, namely equating the terms "loose” and "sound” monetary policies. Nevertheless, the same paper goes on to describe monetary policy as being “...extremely tight” by the middle of 1957 (op.cit., p. 479) without providing an explanation themselves of how the degree of ease or tightness in policy ought to measured. Their plea for greater transparency and clarity, if desirable and welcome from a contemporary perspective, is, nevertheless, firmly rooted in the notion that the monetary and fiscal authorities ought to act as one and that the Bank of Canada's position, which they describe as anomalous (op.cit., p. 465) would be tolerable if there were more Parliamentary oversight. ${ }^{11}$

Others, such as Timlin (1953), and Deutsch (1957), were deeply concerned about the constitutional position, or lack of a proper one, of the Bank of Canada. "One cannot get much enlightenment on this subject by an examination of the formal relationships between the Department of Finance and the Bank of Canada. For one thing, in Canada we have not had the opportunities for education which have arisen elsewhere out of wide-open controversies and public dispute. On this score there has been much sweetness and very little light. ... it is clear that, in case of a serious and basic difference of opinion, a government could force the resignation of the governor. Such a step, however, would be a grave matter before public

\footnotetext{
${ }^{9}$ Nor is this a phenomenon restricted to Canada. McChesney Martin (1957, p.1) is also emphatic on this point. "I refuse to adopt the defeatist position that inflation is the alternative to unemployment.

${ }^{10}$ What was, or was not understood, by policymakers and academics regarding the role and impact of monetary policy during the 1950s, while interesting, cannot be examined in this paper due to space limitations.

${ }^{11}$ Smith (1960), p. 630, n.8) certainly had no difficulty confusing the words "sound" and "tight", while the possibility that the central bank should act independently of the fiscal authorities is not even contemplated, as the opening pages of Gordon and Read (1958, especially p. 468) make clear. Also, see Gordon (1961, p. 16).
} 
opinion. ... Consequently, it may be expected that consultation between Treasury and the Bank is continuous and close. Proposals for important changes in monetary policy are thoroughly discussed between the two authorities, but in the end the responsibility for decision and action in the field of monetary policy rests with the Bank. In other words, there is administrative provision for the close co-ordination of fiscal and monetary policies, but at the same time there is a division of responsibilities and a strong shield against interference in monetary matters.” (Deutsch 1957, p. 220-1)

Neufeld (1958) offers an excellent illustration of the lack of clarity in the oft-cited 1957 Bank of Canada Annual Report (Bank of Canada 1958), when he criticizes the Report for failing to clearly explain why financial markets could not "digest” sufficiently tight monetary policy and, indeed, why there were limits to loosening monetary policy when a recession called for such a policy $^{12}$.

\section{The Spark to the Flame}

The unhappy relationship between the Bank of Canada’s Governor and Donald Fleming, then Finance Minister, first erupted into a crisis following a unanimous decision by the directors of the Bank of Canada to increase Coyne’s pension from $\$ 12,000$ to $\$ 25,000$ on February 15, 1960. As noted by several observers, both the Governor's salary of $\$ 50,000$, and the pension, were several times greater than the remuneration received by members of Parliament or even the Prime Minister (e.g., see Shea 1961). Combined with statements made in earlier years about restraint, and the need for Canadians to live within their means, these events prompted a storm of criticism over the Directors' actions and Coyne’s own competence in the area of monetary policy.

The furor over Coyne’s salary and pension was just a spark to an emerging and more serious controversy over the role and conduct of monetary policy over the previous years. Indeed, Coyne himself would later argue that the pension issue was only an excuse (MacEachern 1961). Never before, and perhaps never since, would a conflict between the Bank of Canada and the federal government be so acrimonious. Indeed, the very issue of the core mandate of the central bank and the sphere of its responsibilities, would come under full scrutiny.

\footnotetext{
${ }^{12}$ There were some economists (e.g., Knox 1959) who maintained the decades old line that inflation was a cyclical phenomenon, rising in booms, falling during a "depression” (op.cit., p. 9) and, therefore, nothing to worry about. As we have seen, others were worried that a permanent rise in inflationary tendencies was underway.
} 
As Figure 2 makes clear, interest rate levels in Canada were both higher and considerably more volatile than comparable U.S. interest rates. One observer (Jackson 1960) subsequently remarked: “The level of interest rates appeared to be at the heart of the controversy". Beyond that, however, was that Coyne's tenure marked a fundamental shift in the Bank's role that was largely precipitated by the fact that he felt the need to communicate more forcefully than his predecessor the position and outlook of the Bank of Canada. In doing so, he brought to the fore the need for monetary and fiscal policies to move in harmony lest there be too much inflation or too little economic growth. Clearly, the government which attained a majority of seats in Parliament in 1958, and the Finance Minister, Donald Fleming, saw Coyne’s approach as amounting to undue interference in the government's economic policies.

It is also important to point out that, throughout this episode, Coyne and Fleming corresponded frequently but never saw the need to meet face to face to discuss how monetary and fiscal policies ought to be coordinated. Nothing in the Bank of Canada Act compelled the Governor and the Government to consult with each other. However, under section 5(2) of the Act in place at the time (Aufricht 1967, p. 90), the Deputy Minister sat on the Bank’s Board as a non-voting member. As a result, the Minister of Finance and the Governor would end up talking, whether in public or in private, at cross-purposes, the former contradicting earlier positions in the name of political expediency, the latter seemingly trespassing in fields normally reserved for ministers announcing government policy. It is precisely the lack of clarity about where the ultimate responsibility for the conduct of monetary policy lies, together with the absence of mechanisms to permit the governor and the Minister of Finance to regularly discuss their views that created conditions which led to a crisis. Hence, whereas Coyne felt it was his duty to point out how government policies could impinge on the conduct of monetary policy one could question how much of his disagreement with the Minister of Finance should have been aired in public.

While it is natural for the Minister of Finance to seek advice from the governor regarding fiscal policy, in particular, and economic policy more generally, one can also second-guess Coyne's decision eventually to go public with his proposals in 1961 to reduce unemployment. ${ }^{13}$

\footnotetext{
${ }^{13}$ Matters came to a head when Coyne made public recommendations for sweeping tax and spending policy changes he had sent to Fleming in February 1961 (Canadian Press 1961). Previously, several individuals, who once supported Coyne, wrote of their dismay over Coyne's attempts to influence government policies (e.g., see Cameron 1960). It should be noted, however, that government policy had adopted a more nationalist tone, and one closer to
} 
Nevertheless, as far as the governor was concerned, there was growing unease over the government using the Bank of Canada as the scapegoat for the economic ills of the country as an election had just passed giving the Conservatives the largest majority in Canadian history. ${ }^{14}$ In letters to Donald Fleming, in 1961, Coyne complained about what role monetary policy was to be able to play in the economic life of the nation, or, as he put it in one letter to Fleming (sent February 16, 1961), “put on the spot”. In the same letter, however, he goes on to label Canada’s economic problems as being of the structural variety and includes a memo entitled "The Requirements of Economic Policy Today” which represents a sweeping statement of the economic policies Coyne supports. ${ }^{15}$ In this letter, Coyne underlines (literally) "The largest single factor in higher interest rates is the size of the Federal Government over-all cash deficit..., and the influence which this deficit or the prospect of this deficit has on the minds of investors.” (op.cit., p.3) It is only in subsequent correspondence (e.g., as in a letter to the Deputy Minister of Finance, Ken Taylor, sent June 2, 1961) that Coyne is “...anxious that there should be no misunderstanding as to the relationship of monetary policy to this matter and the preparedness of the Bank of Canada, as in the past [emphasis added], to cooperate in support of the Government policy when it is decided." 16

Coyne's ability to communicate policy to the public also contributed to raising the stakes in the battle over whether his policies represented the correct prescriptions. "The trouble with Mr. Coyne is that he has attempted to put his analysis in layman's language. He had tried to 'communicate'.” (Moon 1960). This need not have been taken as a compliment since the same article points out that Coyne “... has hinted at some suggestions, though he does not ever come out and make some of these hints into firm suggestions, let alone recommendations, even for consideration.” It should be emphasized that the Governor did not communicate nearly as

some of the views expressed by Coyne himself, and was contemplating more active intervention in foreign exchange markets, a policy also favored by Coyne (Binhammer 1964, Yeager 1976, Siklos 2008).

${ }^{14}$ The elections of June 10, 1957 gave the Conservatives under John Diefenbaker a minority government. This was followed by a massive majority in the elections of 1958 and this, no doubt, gave the government the feeling that it could easily override the policies of the Bank of Canada, when and if this was to prove necessary. Of course, the Conservatives had to face an opposition that held the majority in the appointed body, the Senate, and this was to play a part in the undoing of the Conservatives at the end of the Coyne Affair, as we shall see.

${ }^{15}$ The memo recommends actions in 15 areas including: (1) reduction of imports; (2) mobilisation of capital for investment; (9) minimize deficit finance; (10) national debt reduction; (12) an Unemployment Insurance Fund.

${ }^{16}$ The matter referred to in the quote concerned exchange rate policy. As noted earlier, Canada was to return to the Bretton Woods system shortly after Coyne’s successor, Louis Rasminsky, would take office. Muirhead (1999, p. 169) describes Taylor as “...not a strong deputy minister, while Coyne was a determined man, confident of his abilities and about the direction in which he wished to take the Bank. That strength led to the governor injecting himself into what many considered to be the political process." 
frequently as modern-day central bankers do. Indeed, this may have been part of the problem (see below) since, between June 1957 and October 1959, Coyne did not give a single speech (Coyne 1961a). Subsequently, he gave 14 speeches in the 29 month period between November 1959 and June 1961. Perhaps this explains why Coyne (1961a) later remarked: “The first intimation Mr. Fleming gave me of concern about my speeches was on March 8, 1961.”

As late as 1959, the Minister of Finance, Donald Fleming, asserted that the central bank, and not the government, was responsible for monetary policy. Gordon (1961) interprets the Government’s doctrine as follows: “...the government is responsible for fiscal and debt management policy but not for monetary policy. The Bank of Canada is autonomous in the formulation and implementation of monetary policy.” (op.cit., p.6) As pointed out later by Gordon (1961), this view served to “...confuse both the understanding of economic policy and the working of responsible government.” (op.cit., p. 9) The reason is that the Government failed to act to cushion the interest rate effects in the switch from the maturing World War II Victory bonds to the new long-term Conversion bonds. ${ }^{17}$

A few other features about the Coyne Affair are remarkable from the perspective of discussions in recent years over the place of the central bank. They are: the debate over the importance of accountability and transparency, the appropriate form of central bank governance, and the role played by economists’ views aired in public.

The version of the Bank of Canada Act at the time did not define the role of the government of the day in matters of monetary policy. Indeed, the governor had veto power over the Bank's board although, in the event of a conflict, the Finance Minister was to be informed within a week. Cabinet could then support or disallow the veto. ${ }^{18}$ As Muirhead (1999, p. 168) points out the veto was in place because the Bank was originally a private institution and only subsequently did government become the sole shareholder. As a result, even though the legislation made the Governor the supreme decision-maker, they were subject to oversight by the

\footnotetext{
${ }^{17}$ Unlike 'Operation Twist' in the US, which was a deliberate attempt to manipulate the term structure in the early 1960s, the Conversion Loan reflected a debt management problem. As with Operation Twist, there are differences of opinion in the academic literature about its success. Christofides, Helliwell, and Lester (1976) use the then existing Bank of Canada's RDX2 model to conclude that long-term rates under the Conversion loan rose by about $1 \frac{12 \%}{2}$ while short-term rates were lower than they otherwise would have been. Others, including Pesando (1975), conclude that there were no lasting effects from the introduction of the Conversion loan.

${ }^{18}$ Section 14(1) of the Bank of Canada Act of 1953-54 (Aufricht 1967, p. 92) states: "The Governor, ... has proven to veto any action or decision of the Board of Directors or of the Executive Committee, and if this veto power is exercised, the Governor or Deputy Governor, as the case may be, shall within seven days inform the Minister in writing ... and the Governor in Council who may confirm or disallow the veto.”
} 
Directors, who, by then, were appointed by the government. While the Directors might be under the impression that they were to act independently, or on their own initiative, clearly the government at the time saw things differently. Coyne’s public letter to Donald Fleming, shortly before he resigned on July 14, 1961, made it plain that there was a serious flaw in the governance of the central bank. "The Bank of Canada Act provides that the directors shall appoint the governor, with their choice being subject to approval by Government. Obviously, the directors are intended to exercise their own judgment in this matter, and take the initiative. On June 3, I asked the two directors who had come to Ottawa who they were going to appoint in my place, and the answer was, “We don’t know. We haven’t been told that yet” (Coyne 1961).

It is of crucial importance to remark that Minister of Finance, including Donald Fleming, paid lip service to the notion that day to day monetary policy decisions ought to rest with the central bank, while the overall policy environment should be the responsibility of the government. C.A. Dunning, Minister of Finance at the time the Bank of Canada was created in 1935, stated in 1936: "In the long run, the bank, in the performance of a vital function, must be responsible to the sovereign will expressed through a government. There cannot be two sovereigns in a single state” (as quoted in Muirhead 1999, p. 169). Even Donald Fleming, at the centre of the Coyne affair, is quoted as supporting the views enunciated by one of his predecessors and, in so doing, was to become his own most eloquent critic. In 1961 Fleming stated: "The federal government has no power over the Bank of Canada and is not responsible for its actions” (as quoted in McArthur 1961). Five years earlier, in 1956, and then an opposition member, Fleming would be quoted as saying that: “The government cannot shed its responsibility for full fiscal policy in the broadest sense of the word and that must include the actions of the Bank of Canada” (as quoted in McArthur 1961). Coyne also expressed his views about the role of the Bank of Canada in economic affairs. "My own view is that the government must be supreme in all fields of economic policy, and must accept responsibility in such matters. The Bank of Canada has never set itself in opposition to the government. If there is any economic policy of the government which appears improper for the Bank of Canada, acting in its own sphere, to cooperate with, or if there is any monetary policy desired by the government which the governor of the bank could not in good conscience carry out, I would regard it as the duty of the governor to resign, and I have previously said so” (as quoted in Canadian Press 1961). 
It is tempting to think of this episode as one where the central bank acquiesced in the role of scapegoat while unfavorable economic outcomes could easily be blamed by the government as the fault of the Bank of Canada. However, such a view is entirely misplaced and not in keeping with what was said either in private or in public. First, the Bank of Canada was not statutorily independent of government even if, in public pronouncements, both sides recognized the reality that the ultimate responsibility for monetary policy rests in the hands of the government. Second, the various speeches Coyne made after 1958, together with the blunt language of the Annual Reports, all of which were widely reported and discussed in the media, made it abundantly clear that the Bank of Canada would not allow itself to be treated as the scapegoat. $^{19}$

The upshot is that, at least in the public sphere, it became clear that fundamental questions about the role of the central bank needed to be answered. In the aftermath of the Coyne Affair, the Government of the day would agree to form a Royal Commission, called the Porter Commission, which was to make recommendations about the relationship between the Government and the central bank. Coyne’s successor, Louis Rasminsky, echoing the plea made by his predecessor, would insist on the addition of a Directive into the Bank of Canada Act. The Directive would, ideally, incorporate the expectation that the Governor resign in the event of a policy disagreement with the Government. In the event, the Directive came into being in the 1967 revision to the Bank of Canada Act, but the requirement to resign in case of a policy conflict did not. What was new was the principle of dual responsibility, namely that monetary policy objectives ought to be set by Government, while the day-to-day conduct of monetary policy is exclusively the responsibility of the central bank. The questions being posed over 45 years ago are reminiscent of the debate, during the 1980s and 1990s, over the merits of central bank autonomy and discussions over the public posture of central banks.

Another unprecedented feature of the Coyne Affair was the public involvement of academics in the debate over the conduct of monetary policy. This culminated with the publication of H. Scott Gordon’s (1961a) tirade against Coyne, and monetary policy more generally. However, much of the controversy appeared in the press. It began with a letter written by several economists (see Jackson 1960) calling for Coyne to resign which reached the Minister of Finance on June 8, 1960 although dissatisfaction with the governor's performance began to

\footnotetext{
${ }^{19}$ See also Muirhead's (1999, p. 179-82) brief account of the Coyne affair.
} 
surface earlier. The text of the letter (e.g., Jackson 1960) expressed how the economists were “...puzzled and distressed by the economic reasoning contained in these public statements.” (of the governor). The original letter, at least as published in the press, does not, however, stipulate the exact nature of what puzzled these economists. The economists who signed the letter were, however, clearly unhappy with Bank of Canada monetary policy.

Smith and Slater (1961), two well-known economists, called Coyne to task for errors of judgment. Specifically, they criticize Coyne for "overemphasizing inflation”. They were also critical of Coyne's worries over the consequences of (long-term) capital inflows and the need to consider some controls.

The best known of Coyne's critics at the time, and the leader of the movement that produced the letter to Fleming, H. Scott Gordon, eventually produced a pamphlet outlining his views (Gordon 1961a). Although a variety of accusations were made against Coyne and the Bank, the two that are relevant to this paper include: an over-emphasis on fighting inflation, and stepping beyond the normal bounds for a central banker. The first criticism is one that was leveled by other critics but, as noted above, the government had no formal mechanism to override the Bank's monetary policy strategy if it disagreed with it. Gordon drew attention to the behaviour of the money supply during Coyne's tenure. As shown in Figure 6, there were two sharp drops in the money supply, the first at the end of 1957 which precipitated the recession of 1958, and the second, a far milder contraction in 1959. However, the same Figure also reveals that the monetary base did not fluctuate as much. It is certainly feasible, therefore, that the proximate cause was a drop in money demand and not an excessive tightening, or a delay in loosening of policy, as some of Coyne's critics claims (e.g., Gordon 1961), a possibility understood by some economists at least. ${ }^{20}$

A second accusation made by Gordon is that Coyne essentially overstepped his authority in matters of economic policy making. It was pointed out earlier that Fleming's predecessors, and Coyne himself, understood the conditions under which a governor should resign in the event of a conflict over the strategy of monetary policy. However, in the absence of a formal mechanism to resolve such conflicts, the resulting vacuum precipitated the crisis. As a trenchant

\footnotetext{
${ }^{20}$ An unresolved issue us to what extent the sharp drop in the money supply was 'manufactured' by the Bank of Canada. The Bank's 1957 Annual Report mentions the need to make adjustments to ensure comparability in the data but, instead of providing a clear statement of the problem, simply asserts the need to make changes in the data. The issue of the "shallow statistical trick" was raised by Gordon (1961), but is dismissed in Bellan (1961), and in the 1958 Annual Report (Bank of Canada 1959).
} 
review of Gordon's analysis remarks: "If Mr. Coyne is now free to set his own policies, it can only be because the present Minister of Finance, Mr. Fleming, allows him that freedom” (Bellan 1961).

The Coyne Affair ended quickly. Hence, we can be brief. The Conservative government introduced a bill on 23 June 1961consisting of a single sentence that read: "The office of the Governor of the Bank of Canada shall be deemed to be vacant immediately on the coming into force of this Act.” The bill was passed quickly by the Conservatives but the Senate, where the Liberals held a majority, supported the Governor's position. Coyne’s position was helped when it was revealed that at least two of the Bank's directors were politically influenced and that the Minister was less than truthful in recollecting events surrounding the pension issue. The Senate failed to give assent to the government's bill, concluding that the Governor's actions did not violate the Bank of Canada Act, thereby permitting Coyne to resign on July 12, 1961, “... honorably, and to hold up my head among my fellow citizens ...” (Coyne 1961).

\section{Empirical Evidence}

As the previous sections hopefully made clear, the controversy that eventually engulfed the Governor of the Bank of Canada revolved around whether the stance of monetary policy was appropriate under the circumstances. In this connection, it is important to consider that, even nowadays, if hindsight favors one view over another, this is only because researchers likely have the data that has been subsequently revised, sometimes significantly so. This is one of the lessons of Orphanides (2001) who revisits the Fed's policies during the 1970s and 1980s. As we have seen, this is especially relevant when revisiting policies that eventually culminated in the Coyne Affair.

Another area of contention is likely to revolve around whether any central bank during the 1950s could be forward-looking as opposed to reacting solely to past events. Whereas central banks today are almost certainly forward-looking, the evidence presented in the previous sections paint a somewhat different picture. In particular, while there is some evidence the Bank of Canada was aiming to think ahead when deciding whether or not to tighten or to loosen policy, there was a strong element of backward-looking thinking going on as well. This should not be surprising. After all, it must be recalled that the operations of the Bank of Canada had undergone a profound transformation in the early 1950s, namely the move to a floating exchange 
rates and the adoption of the interest rate benchmark that would henceforth serve as the mechanism to evaluate the stance of monetary policy.

The empirical evidence generated in the paper proceeds on the assumption that the central bank potentially reacted to inflation and to overall economic developments. Although the Taylor rule device is used to assess the Bank of Canada's policies this only serves as a vehicle to translate the Banks’ thinking during the period 1952-1961. ${ }^{21}$

A standard Taylor rule is written as follows:

$$
i_{t}=\bar{i}+\gamma_{\tilde{\pi}} \tilde{\pi}_{t}+\gamma_{\tilde{y}} \tilde{y}_{t}+\rho i_{t-1}+v_{t}
$$

where $i_{\mathrm{t}}$ is the nominal interest rate instrument of monetary policy, $\bar{i}[=(1-\rho) \alpha]$ is the sum of the steady-state real interest rate and the annual inflation rate, $\tilde{\pi}$ and $\tilde{y}$ are, respectively, inflation and the output gap, $\rho$ is the interest rate persistence or smoothing parameter, and $v_{t}$ is a residual term. $^{22}$ Similarly, the output gap is the percent deviation of real GNP from its potential level. The coefficients $\gamma_{\tilde{\pi}}[=(1-\rho) \beta]$ and $\gamma_{\tilde{y}}[=(1-\rho) \theta]$ reflect the weights policy makers place on inflation versus the output gap, while the central bank's reaction to output versus inflation is captured via estimates of $\beta$, and $\theta$, respectively, the steady state responses of interest rates to inflation and the output gap. If contemporaneous inflation and output are unobserved but respond to the past history of these variables and, in turn, influence their expected values, they are endogenously determined. The coefficients in the reaction function are obtained from an expression that summarizes the interest rate instrument targeting policy of the central bank, namely:

$$
i_{t}^{T}=\alpha+\beta E_{t}\left(\tilde{\pi}_{t+i}\right)+\theta E_{t}\left(y_{t+k}\right)
$$

where $i_{t}^{T}$ is the interest rate target, $E_{t}\left(\tilde{\pi}_{t+i}\right)$, and $E_{t}\left(\tilde{y}_{t+k}\right)$ are the conditional expectations of inflation and the output gap, $\mathrm{i}$ and $\mathrm{k}$ periods ahead $(\mathrm{i}, \mathrm{k} \geq 0)$. Since $E_{t}\left(\tilde{\pi}_{t+i}\right)$, and $E_{t}\left(\tilde{y}_{t+k}\right)$ are

\footnotetext{
${ }^{21}$ Originally, I had planned on estimating a small structural model of the kind that academics during the 1950s used in debating monetary policy issues. This proved impossible for several reasons. First, models at the time were generally not estimated so there is no empirical basis for comparison. Second, there were essentially no attempts to hypothesize the anticipated size of coefficients, and predictions from such models were largely based on "best guesses" about which forces were relatively most important. I also considered the possibility of examining a counterfactual experiment whereby the exchange rate would be assumed fixed. However, as Figure 3 makes plain, except at the very end of Coyne's tenure, exchange rate fluctuations were very small.

${ }^{22}$ If there were an explicit, or even implicit target for inflation, then $\tilde{\pi}$ would represent the deviation from such an objective. Other than a desire for "low" inflation, there is nothing to suggest that policy makers, or even academics, during the 1950s had any numerical target in mind. We return to this question below.
} 
unobservable, instruments can serve as proxies. Good proxies are generally difficult to find and the difficulty is likely to be even more acute in the present context. However, given the earlier discussion concerning the role of monetary aggregates, US economic developments, and the behaviour of the current account, it is of considerable interest to ask whether these might serve as relevant instruments. This is the econometric equivalent of asking whether the Bank of Canada effectively took such data into consideration when helping guide interest rate movements.

Previously, it was also argued that monetary policy in Canada could not be easily distinguished from U.S. developments. Therefore, as an alternative, it seems useful to also consider a version of (1) that captures Canada's monetary policy relative to that of the U.S. Define $i^{*}, \tilde{\pi}^{*}$, and $\tilde{y}^{*}$ as the differential between Canada's (C) interest rate, inflation rate, and output gap, relative to their counterpart for the US (US). As a result

$$
\begin{aligned}
& i_{t}^{*}=i_{t}^{C}-i_{t}^{U S} \\
& \tilde{\pi}_{t}^{*}=\tilde{\pi}_{t}^{C}-\tilde{\pi}_{t}^{U S} \\
& \tilde{y}_{t}^{*}=\tilde{y}_{t}^{C}-\tilde{y}_{t}^{U S}
\end{aligned}
$$

Next, following Mark (2005), I estimate a version of the Taylor rule where the policy instrument is $i_{t}^{*}$. This results in an instrument rule of the form

$$
i_{t}^{*}=\delta+\gamma_{\pi^{*}} \tilde{\pi}_{t+i}^{*}+\gamma_{\tilde{y}^{*}} \tilde{y}_{t+j}^{*}+\rho i_{t-1}^{*}+u_{t}^{*}
$$

Equation (6) is simply a conventional Taylor rule expressed in differences between Canada and the U.S. ${ }^{23}$

I rely not only in the available historical data published subsequently - I will refer to this as the quasi-final data - but also on 'real time' data. The latter were constructed by collecting quarterly Gross National Product data from the Dominion Bureau of Statistics for several vintages beginning in 1953 through $1963 .^{24}$ An appendix provides additional details. The quasifinal data, based on a 1972 vintage of data, are from Cayen and van Norden (2005) who made available their GNP time series that also begin in $1952 .{ }^{25}$ Data for interest rates and prices are

\footnotetext{
${ }^{23}$ As Mark (2005) points out, equation (6) is obtained by assuming homogeneity in cross-country coefficients for expected inflation and the output gap. We also estimated versions of (2) and (6) with a nominal exchange rate term, but our conclusions are unchanged. It would have been preferable to add a terms of trade measure. However, I was unable to construct a consistent quarterly series for the 1950s.

${ }^{24}$ A total of 21 vintages were collected, one for the second and fourth quarters of each year beginning with 1953Q4 and ending with $1963 \mathrm{Q} 4$.

${ }^{25}$ Berlinguette (1954) provides a detailed account of the problems surrounding the construction of aggregate output data during the 1950s in Canada.
} 
final, not real time data while US data are quasi-final data and real time observations. The relevant interest rate, CPI, and GNP data were collected from the Banking and Monetary Statistics publication of the Board of Governors of the US Federal Reserve System. ${ }^{26}$ Vintage US data were collected from various issues of the Survey of Current Business. One difficulty with both Canadian and US data is the absence of quarterly constant dollar GNP data during the 1950s in real-time. For Canadian data, a real GNP figure was constructed using a proxy for the implicit price deflator calculated from the data used in Cayen and van Norden (2005). For the US, the implicit price deflator was estimated from real GNP estimates in Balke and Gordon (1989). The deflator for both countries is not real time data. For the quasi-final data I was able to use available real GNP estimates for both countries. Finally, I also tried but was unsuccessful, in creating a real time data set for different definitions of the money supply. Instead, I rely on the monetary base from CANSIM II (series v37145), as well as the monetary base, M1, and M2 series from Metcalfe, Redish and Shearer (1998) whose data are available from www.econ.ubc.ca/redish/research.htm. ${ }^{27}$ Their monthly data were converted into the quarterly frequency via simple averaging. US money stock data are from Balke and Gordon (1989).

I now turn to more formal evidence to examine the behaviour of the Bank of Canada. A simple AR(1) model of inflation for the US and Canada produces virtually identical estimates of the persistence parameters with an estimate of 0.66 for Canada, and 0.68 for the US (both are statistically significant at the $1 \%$ level). To place these estimates into some perspective, these are lower than estimates obtained for the period of high inflation in the 1970s and 1980s, but are higher than estimates that have been reported for the low and stable inflation rates since the 1990s (e.g., see Siklos 1999, Burdekin and Siklos 1999). In contrast, the 90 day Treasury bill yield for Canada displays a considerable amount of persistence (0.84), again based on the same AR(1) model, as well as considerable explanatory power (adj $\mathrm{R}^{2}=0.72$ ). Although $\mathrm{AR}(1)$ models are simple, they shed light on the process driving inflation and interest rates. Hence, while nominal interest rates may have been volatile during the 1950 s, they were predictable. ${ }^{28}$

\footnotetext{
${ }^{26}$ As several studies have shown (e.g., see Cayen and van Norden 2005), revisions to CPI and interest rate data are minimal.

${ }^{27}$ Data obtained from the Bank of Canada Archives (Freeman 1959) match very nearly the data for the same period presented by Metcalfe, Redish and Shearer (1998).

${ }^{28}$ Estimates of persistence in Canadian and US inflation rates are based on the sample 1952Q1-1962Q4, and for the nominal interest rate the sample is 1953Q1-1962Q4.
} 
Turning to estimates of a Taylor type rule, Figure 7 summarizes estimates of the steady state parameters for the output gap ( $\theta$ in equation (2)) and the real interest rate ( $\alpha$ in equation (2)), using the Taylor rule written as in equation (1). Coefficients are estimated via OLS for 10 vintages beginning with the 1954Q4 vintage, which yields 23 observations, up to the 1963Q4 vintage, which yields 44 observations. The inflation parameter, whether estimated contemporaneously or with a one period lag, was never statistically significant. Instead, the highest p-value recorded for $\gamma_{\tilde{\pi}}$ in equation (1) was 0.20. By contrast, the coefficients for the output gap and the constant ( $\bar{i}$, and $\gamma_{\tilde{y}}$ in equation (1)) were always highly significant at $10 \%$ levels or less, except for the 1957Q4 and 1959Q4 vintages.

The box plots give the median estimates for the two parameters described above, while the boxed area represents the third (top) and first (bottom) quartiles, respectively. The shaded area is a 95\% confidence interval for the median. As the shaded and boxed areas do not overlap this implies that most estimates of the response of the Treasury bill rate to the output gap are statistically significantly different from the median. In particular, the Bank of Canada appears to have responded especially vigorously to the output gap in vintages 1957Q4 and 1959Q4, precisely at critical junctures in the Coyne controversy. The fact that these steady state coefficients are statistically insignificant suggests that they are very imprecisely estimated. Nevertheless, the mere fact that the version of the instrument rule behaves as shown in Figure 7, relative to all the other vintages, implies that monetary policy reacted differently at those crucial moments. Turning to estimates of the steady state real interest rate, the sheer volatility of the real interest rate is glaringly apparent. Indeed, the estimated real interest rate for the 1959Q4 vintage is an outlier at $11 \%$. Moreover, the median response at over $4 \%$ exceeds the third quartile so that, on balance, the Bank's monetary policy appears to have been exceedingly tight on those two occasions. Otherwise, the bulk of the distribution is well within historical estimates of the longrun real interest rate. Whether these transitory, but sharp, monetary policy responses are the spark that led to the events of 1959-60 is unclear, but at least the data give some hints at what may have produced the conflict that eventually led to James Coyne's departure from the Bank of Canada. 
Next, I turn to estimates of the coefficients in the Taylor rule based on (6), where differences between US and Canadian series are based on real time data for both countries. ${ }^{29}$ Figure 8 plots the range of parameter estimates where $\mathrm{i}=0,2$. The results indicate that the degree of interest rate smoothing was significantly reduced between 1958 and 1960. The resulting fluctuations in nominal interest rates are precisely the ones that observers complained about when assessing monetary policy performance in Canada. Mean estimates of the steady-state real interest rate also vary considerably across the 9 vintages examined. However, median estimates do not change much. Nevertheless, it is clear that real interest rates were high in the late 1950s relative to almost every later vintage. Turning to the inflation response, it is found that most estimates are imprecise with the shaded area, indicating the $95 \%$ confidence interval around the median, overlapping the zero response value. Yet, it is interesting to note that steady-state responses are near or exceed 1 until the 1959Q4 vintage, that is, consistent with the Taylor principle. Thereafter, the mean responses are well below one. Note also that there are outlier responses for some of the reaction function estimates. Hence, on this basis, one cannot exclude the possibility that the Bank of Canada's reaction to inflation may have been excessive until 1960Q2, at least relative to US monetary policy and precisely until the quarter when Coyne resigns. The coefficients are either insignificant, especially until 1959Q4, indicating the Bank of Canada did not consider output gap developments, or they are imprecisely measured beginning with the 1960Q2 vintage.

If the equilibrium interest rate was high, perhaps it is because the central bank's implicit target for inflation was low. To investigate this possibility, I adopt the approach of Kozicki and Tinsley (2007) to derive an implicit inflation target. Starting from equation (6), and setting i=0, 1 combine it with a dynamic adjustment of the interest rate modelled as

$$
i_{t}^{*}=\beta_{0} \Delta i_{t-1}^{*}+\left(1-\beta_{0}\right) \delta^{*}+\beta_{1} i_{t-1}^{*}+v_{t}
$$

where $\delta^{*}$ is the equilibrium real interest rate, and all other terms were previously defined. Next, combining (6) and (7) gives

$$
i_{t}^{*}=\tau_{1}+\tau_{2} \tilde{\pi}_{t}^{*}+\tau_{3} \tilde{y}_{t}^{*}+\tau_{4} \Delta i_{t-1}^{*}+\tau_{5}\left(i_{t}^{*}-\left[i_{t}^{*}-\pi_{t}^{*}\right]\right)+v_{t}
$$

\footnotetext{
${ }^{29}$ Matching US and Canadian data in real time is difficult as the precise release dating of National Accounts data is unclear after the first two vintages. For US data we took, for example, the November release to be the fourth quarter vintage. The first quarter vintage is taken to be the February release; the second quarter vintage is the May release, while the third quarter vintage is the August release.
} 
Equation (8) is estimated vial OLS and GMM (with the same instrument sets as before; also see notes to Figure 2) for 9 separate vintages, while the expression for the central bank's inflation target, expressed here as a target in the differential Canada-US inflation rate, is

$$
\tilde{\pi}_{T}^{k}=\frac{-\tau_{1}}{\left(\tau_{2}+\tau_{5}\right)-1}
$$

Table 1 provides the results. It is clear that, other than for the earlier vintages when the Canada-US inflation differential target was small or statistically insignificant, the Bank is seen as permitting a slight upwards drift in the inflation differential. Therefore, it does not appear that the Bank was more averse to inflation than its US counterpart.

The empirical evidence presented here is suggestive of the possible overreaction at times of the Bank of Canada to inflationary developments. Whether the estimates are conclusive is another matter, as the combined narrative and econometric evidence is not entirely clear concerning the extent to which the Governor, in particular, wanted to pre-empt or eliminate inflationary pressures in the Canadian economy. Therefore, paraphrasing the wonderful expression used in Scottish Courts for the situation where the prosecution did not provide sufficient evidence of guilt, but where there are considerable doubts about the offender's innocence, the verdict on the Coyne Affair is 'not proven'.

\section{Conclusions}

As we have seen, the Coyne Affair focused policy makers' minds on clarifying the limits of the responsibility of the Governor in dictating the adoption of a particular monetary policy strategy. To be sure, the evidence presented in this paper cannot, without a shadow of a doubt, exclude the possibility that an inadequate understanding of macro policy during the 1950s played a role in this episode. Nevertheless, the 'real-time' data, together with the econometric evidence, does not entirely support this view. Instead, it was primarily institutional failure combined with, at times, an overt ideology strongly biased toward the maintenance of price stability at all times, that contributed to the events of 1958-1961. ${ }^{30}$

Shortly after Louis Rasminsky took office as Governor, Canada rejoined the Bretton Woods system. Monetary independence was then effectively lost for over a decade until Canada once again returned to a flexible exchange rate system. In such an environment conflict between

\footnotetext{
${ }^{30}$ Another contributing factor may have been the absence of a committee decision-making structure for monetary policy, unlike the US's FOMC. An exploration of this issue is, however, beyond the scope of this paper.
} 
the government and the central bank was less likely. However, a conflict of sorts re-emerged once Canada adopted inflation targeting in the early 1990s. The ensuing dispute between John Crow and the incoming Finance Minister, Paul Martin, did not produce the same drama that marks the Coyne Affair in Canadian economic history. A significant part of the explanation has to do with the relative clarity of the present Bank of Canada Act concerning the responsibility of the government over matters of monetary policy strategy. Another explanation was an understanding, only emerging at the time and requiring some fine-tuning, about the crucial role played by a central bank's communications strategy. These are some of the most important lessons learned in Canada from the Coyne Affair, and ones that have implications for central banks around the world. While the lessons learned are perhaps old ones, and repeated in different parts of the world at different times, they bear repeating for the failure to heed them can have disastrous implications for both the central bank and the government in office. 
Figure 1 Inflation and Unemployment Rates in Canada and the United States
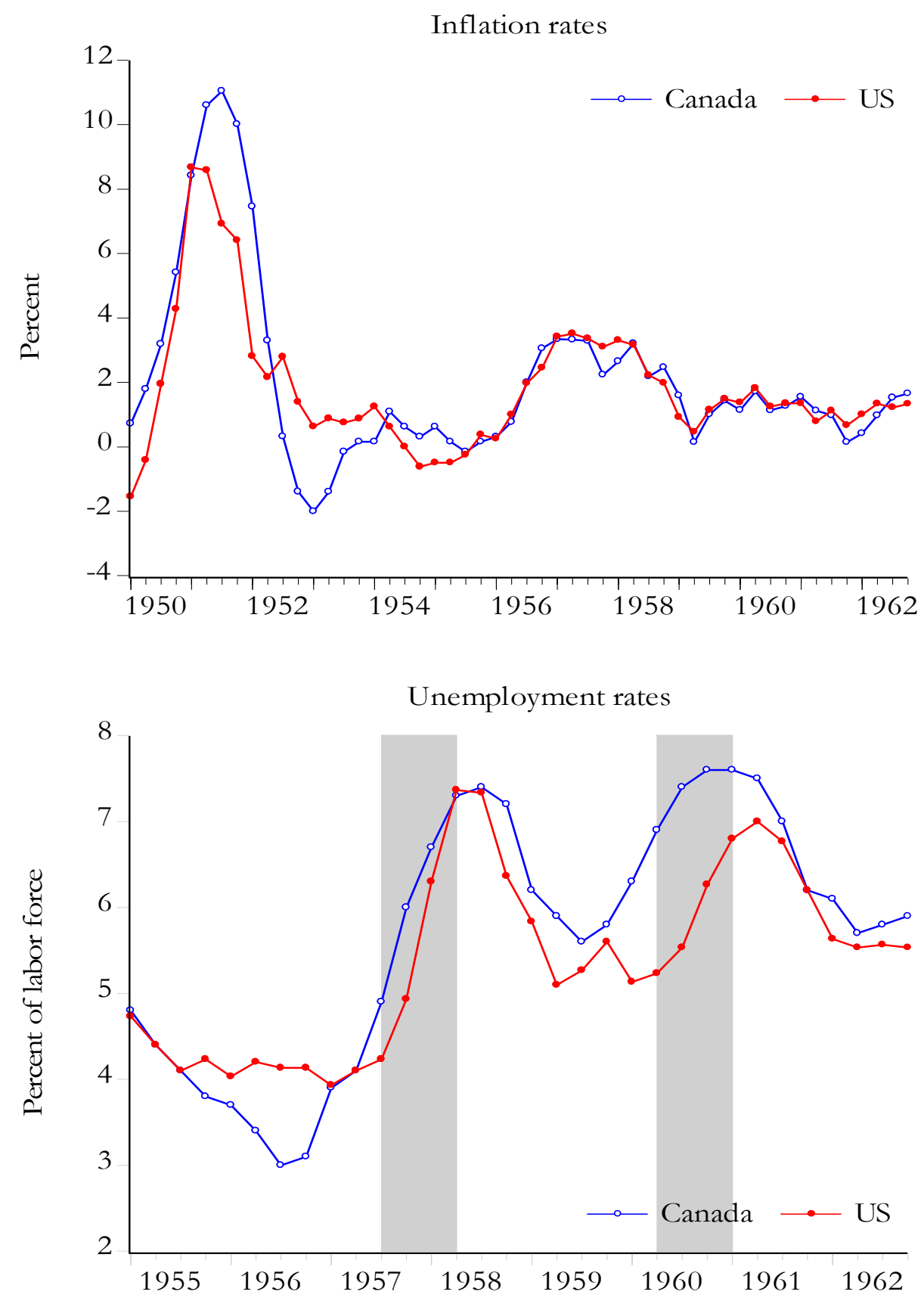

Note: Inflation in Canada is 100 times $\left(\log \mathrm{P}_{\mathrm{t}}-\log \mathrm{P}_{\mathrm{t}-4}\right)$. Data are quarterly from CANSIM. Unemployment data are from Historical Statistics of Canada (Statistics Canada, 11-516-XIE). US data are from FREDII, Federal Reserve Bank of St. Louis, and Survey of Current Business (various issues). The shaded areas represent US recessions as measured by the NBER's business cycle chronology available at www.nber.org. 
Figure 2 Short-term and Long-term Interest Rates in Canada and the US

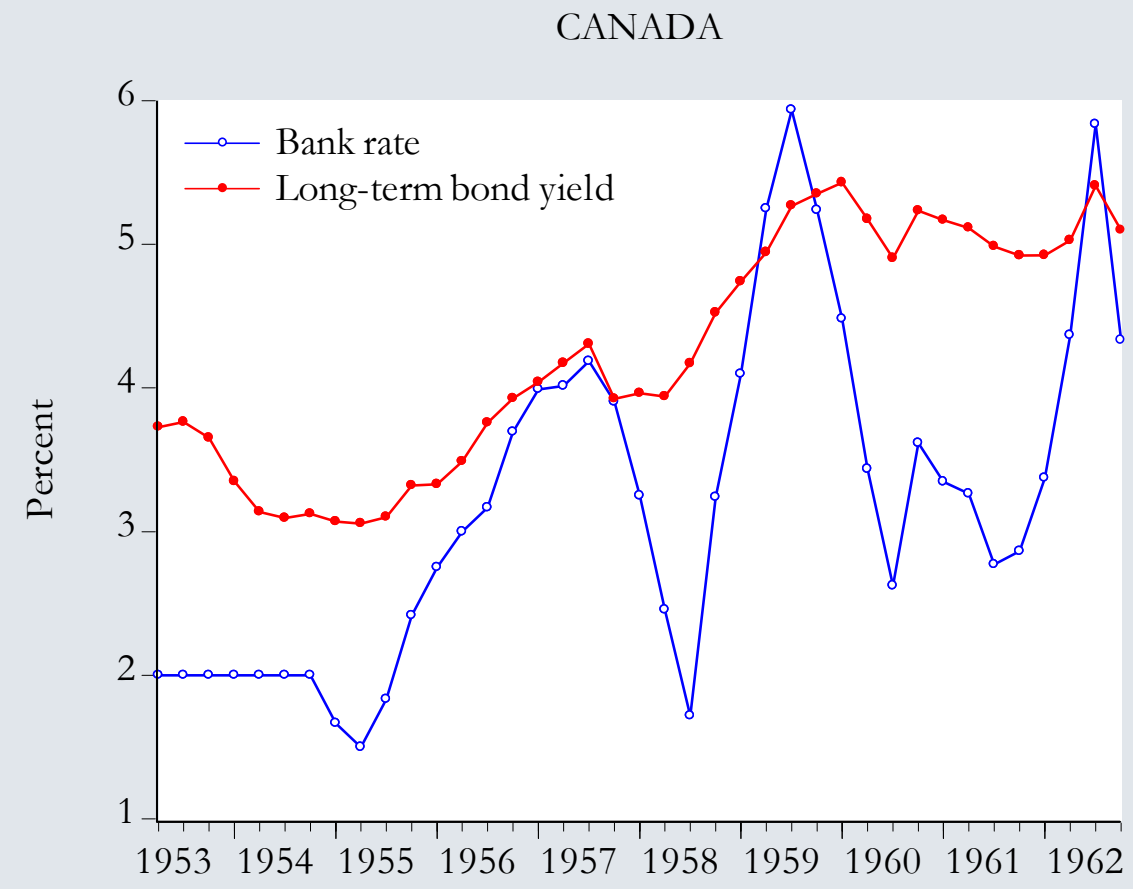

US

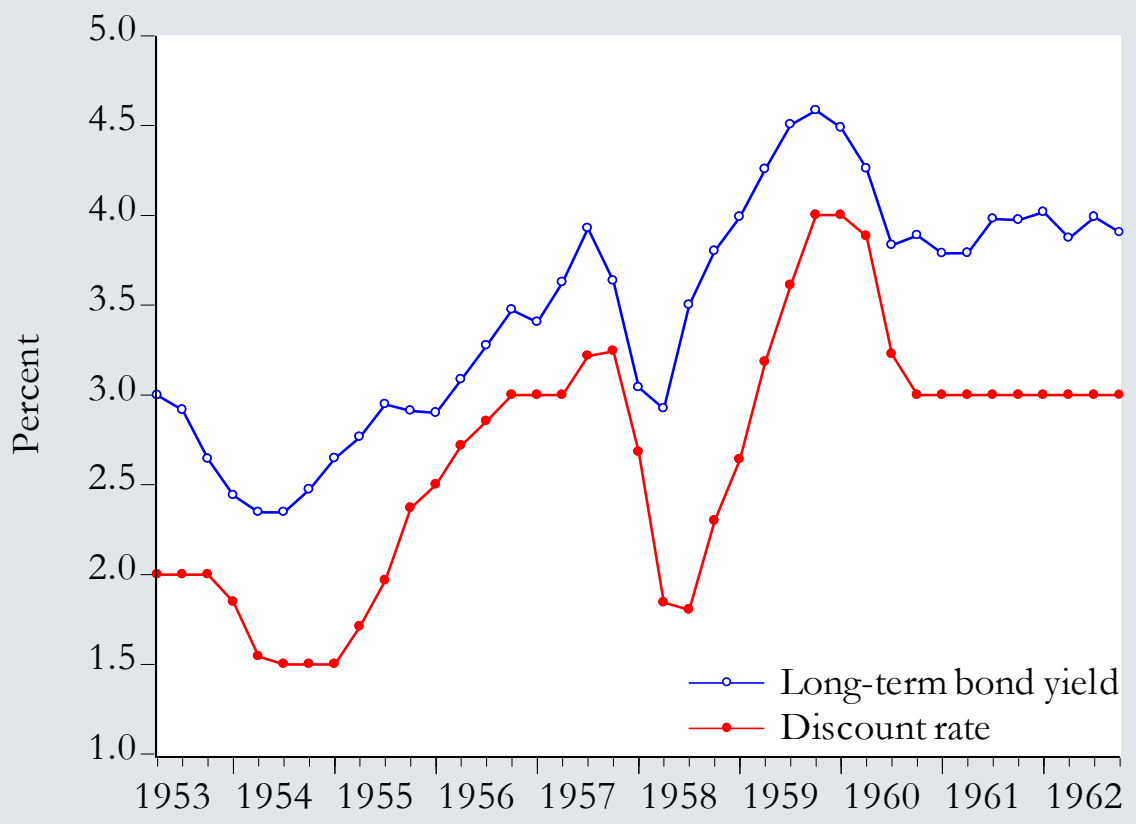

Sources: Bank of Canada, and Board of Governors of the US Federal Reserve. 
Figure 3 Nominal Exchange Rates During the 1950s in Canada

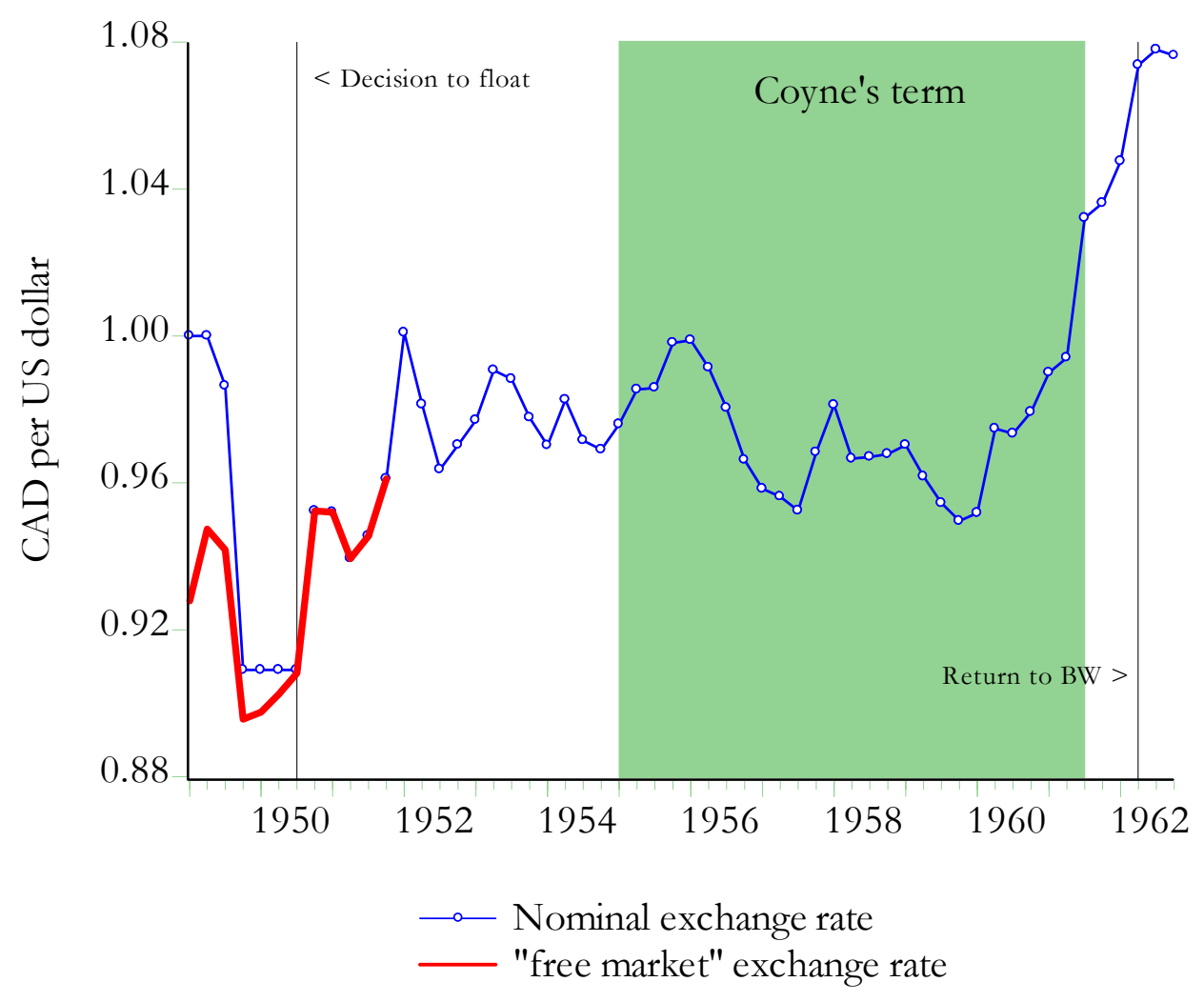

Note: Data are from Bank of Canada, and Bank of Canada Archives. 
Figure 4 Output Gaps in Canada: Real Time and (Quasi) Final Estimates
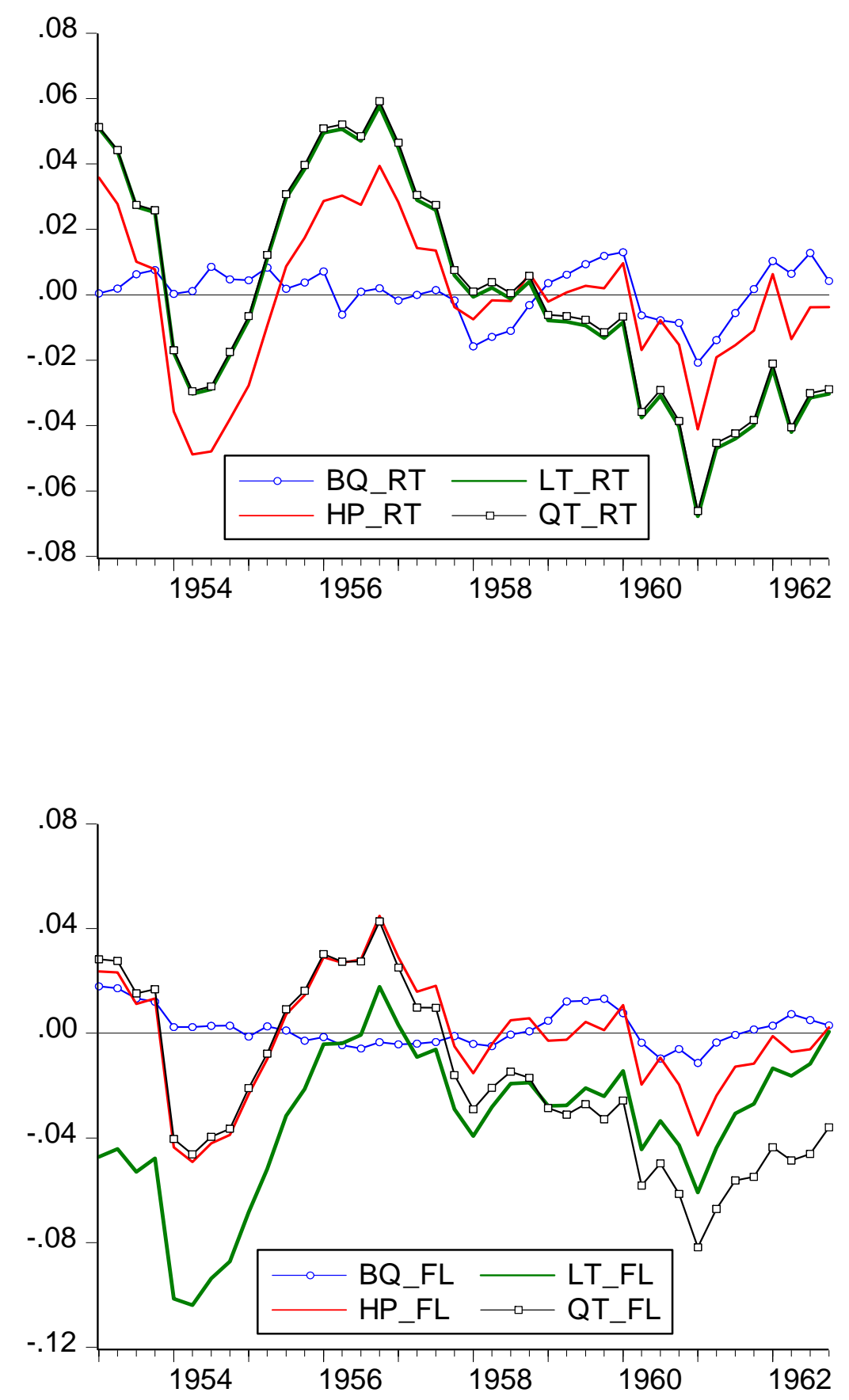

Note: Data are from Cayen and van Norden (2005). RT is real time data collected in 1972; FN is final data based on data collected from CANSIM. BQ (Blanchard-Quah), LT (linear trend), HP (Hodrick-Prescott; smoothing parameter $=1600$ ), QT (quadratic trend) are the filters used to estimate potential output. The output gap is $y_{t}-y_{t}^{P}$ where $y_{t}$ is actual log real GNP and $y_{t}^{P}$ is the estimate of potential output. 
Figure 5 Output Gaps in Canada: Comparing the 1957Q4 and 1960Q2 Vintages
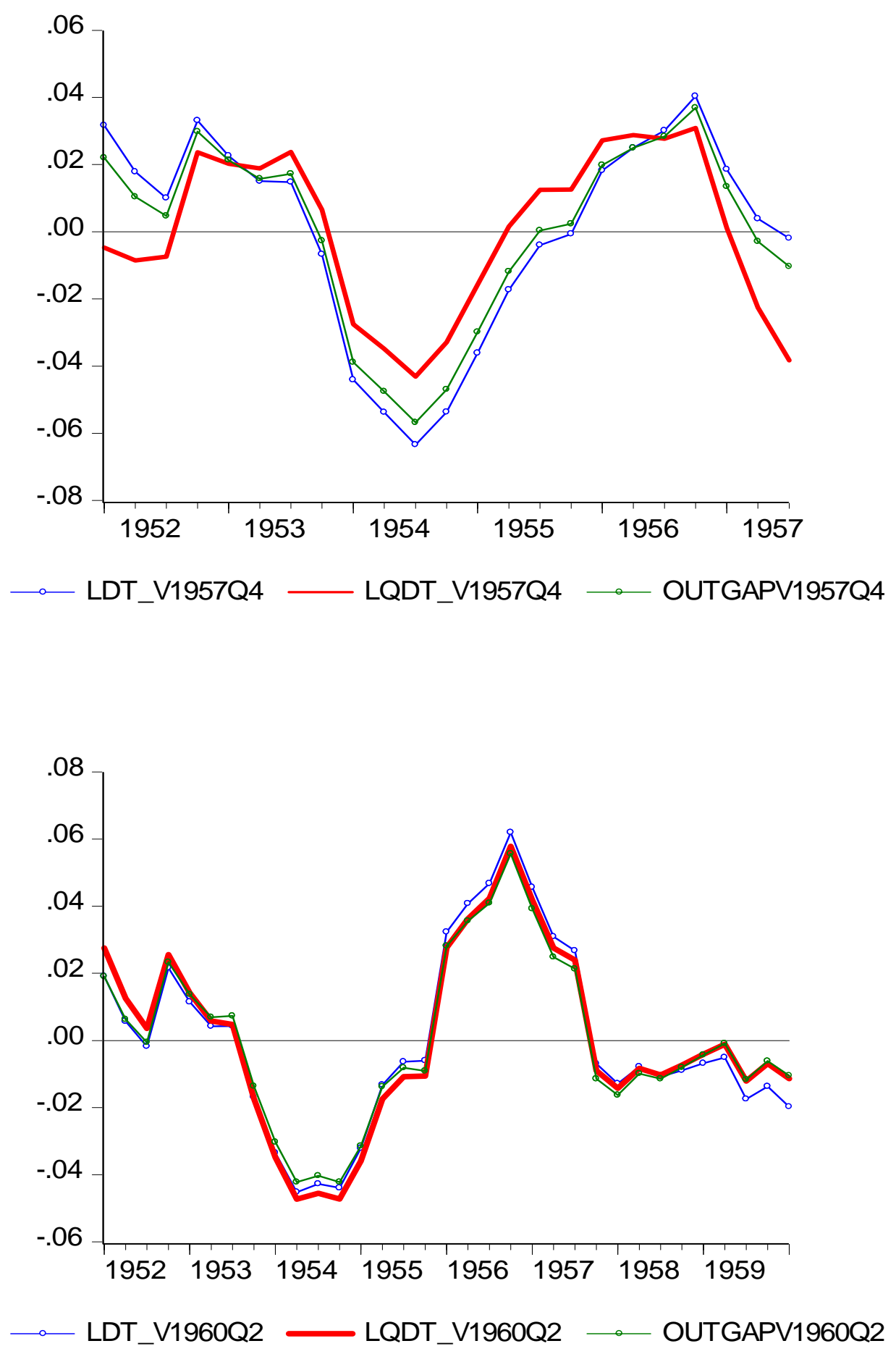

Note: Data are for the 1957Q4 and 1960Q2 vintages. See the appendix for an explanation. LDT means linear detrending, LQDT means quadratic detrending, OUTGAP means the output gap is estimated using an H-P filter (smoothing parameter $=1600$ ). 
Figure 6 Money Supply in Canada, 1954-1962

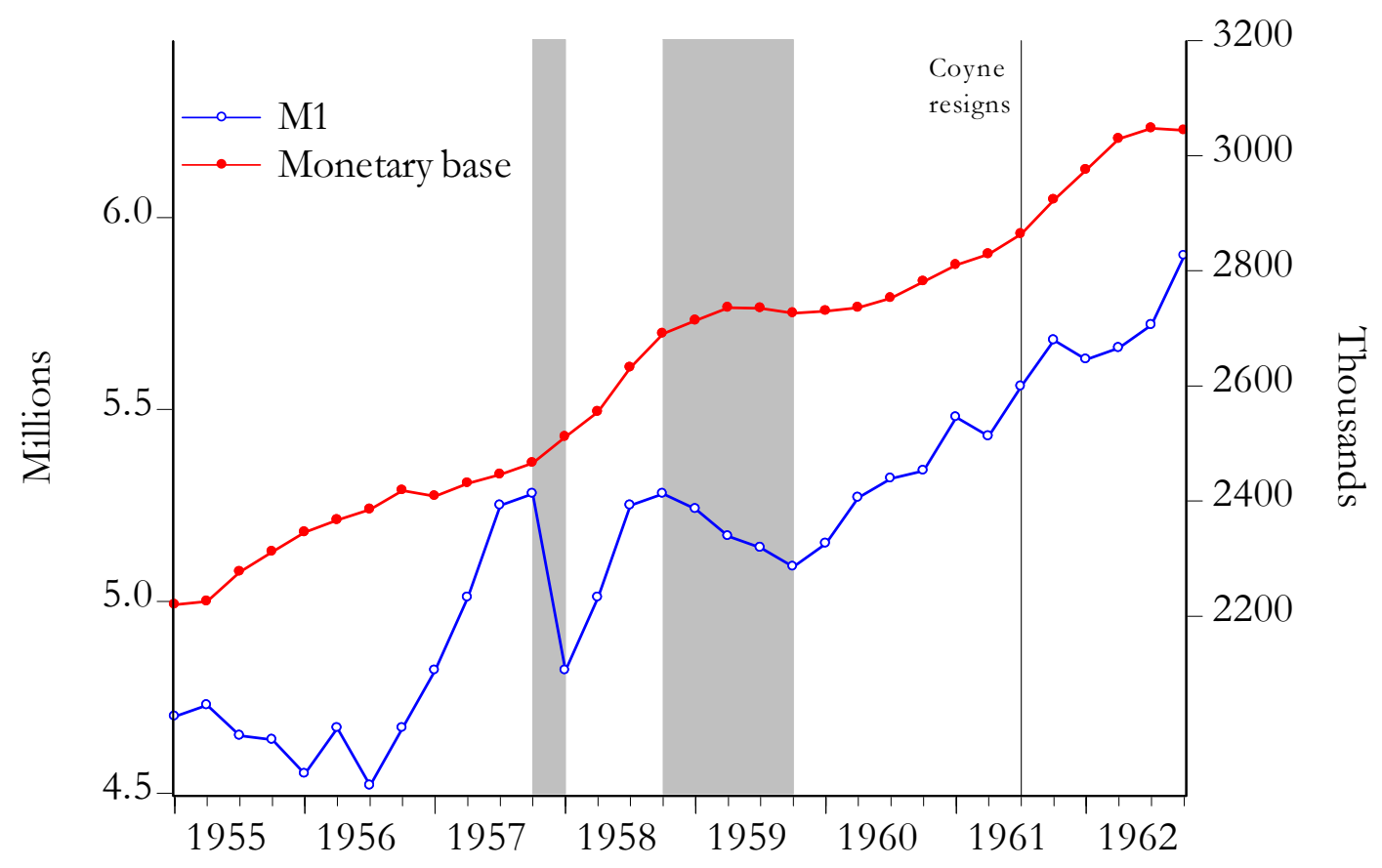

Note: Data are from CANSIM, and Metcalfe, Redish, and Shearer (1998). The shaded areas highlight episodes of possibly sharp reductions in the money supply. See the text for the details. 
Figure 7 Range of Coefficient Estimates for Steady the State Real Interest Rate and Output Gap

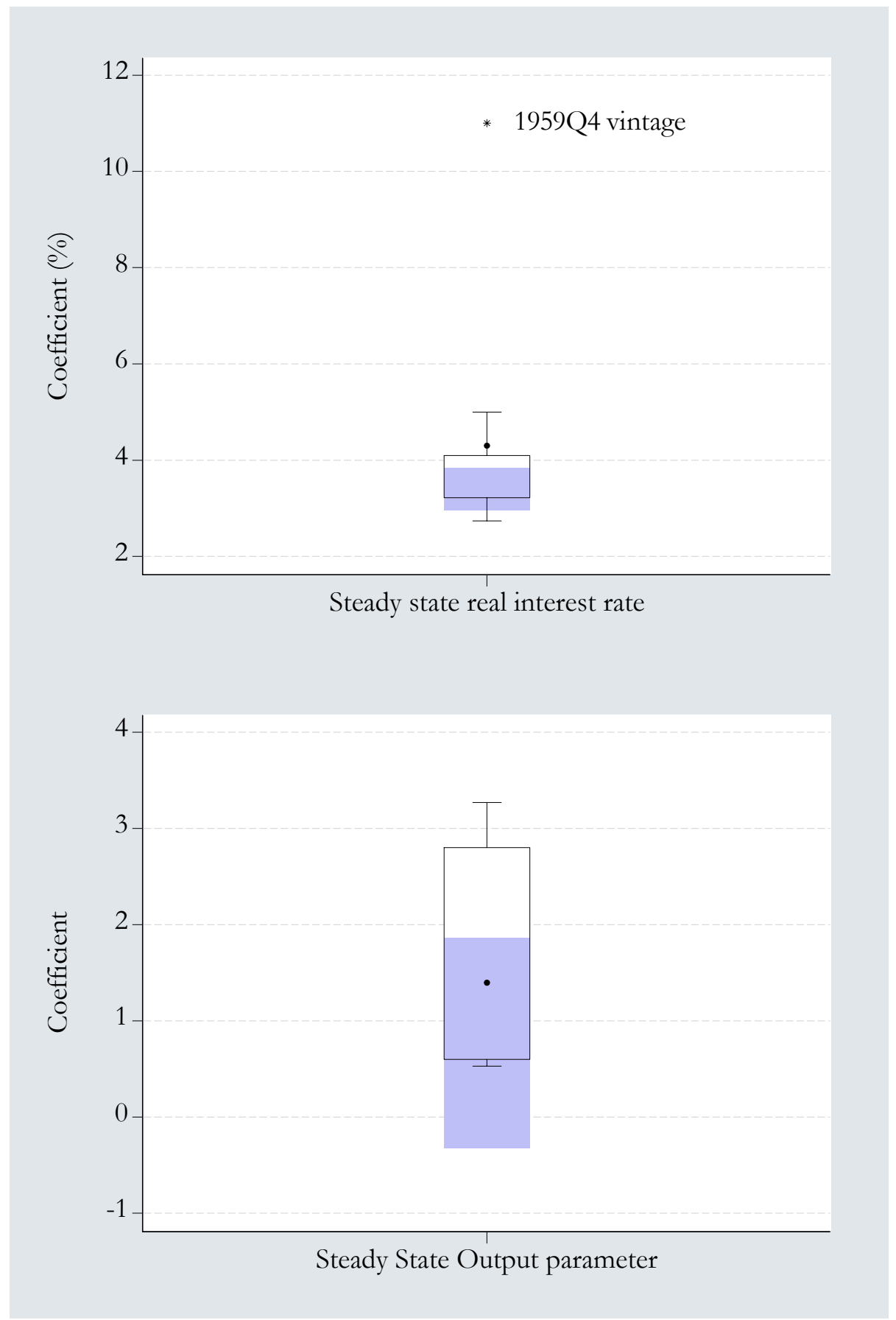

Note: The top figure give the range of estimates for $\alpha$ (see equation (1) and (2)) while the bottom figure gives the range of estimates for $\theta$ (again, see equation (1)). The box plot and shaded areas are explained in the text. 
Figure 8 Range of Coefficient Estimates for Difference Rules: Real Time Data, 1957-1961

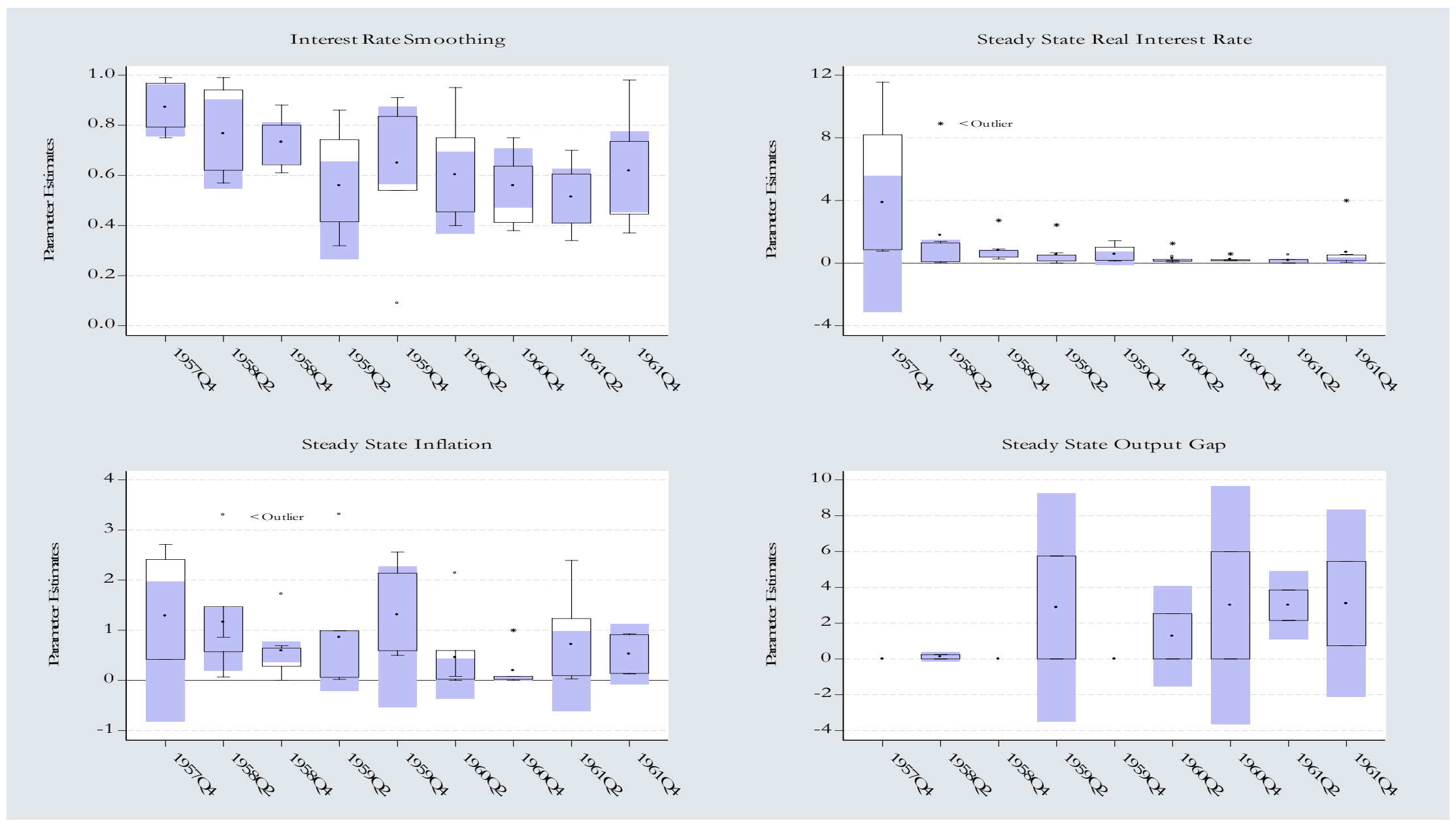

Note: Coefficient estimates are estimated via GMM. $\pi_{t+i}^{*}, \tilde{y}_{t+j}^{*}$ indicates the value of $i, j$ combinations used in estimation. The standard set of instruments consists of a constant, 2 lags in the Treasury bill yield differential, 2 lags in the output gap differential, and 2 lags in the inflation differential. The extended set of instruments consists of the standard set augmented by 2 lag in the long-term interest rate differential, 1 lag in the differential money base growth rate, and 1 lag in the current account to GNP ratio. 
Table 1 The Bank of Canada's Implicit Target for the Canada-US Differential Inflation Rate

$\begin{array}{llccc}\text { Vintage } & \begin{array}{l}\text { OLS } \\ \text { estimates } \\ (\%)\end{array} & \text { Test statistic } & \begin{array}{c}\text { GMM estimates } \\ (\%)\end{array} & \text { Test statistic } \\ \text { 1957Q4 } & 0.25(.01) & 6.15 & 0.04 & 0.06(.80) \\ \text { 1958Q2 } & 0.33(.01) & 6.21 & 0.17 & 2.44(.12) \\ \text { 1958Q4 } & 0.39(.00) & 10.01 & 0.32 & 2.74(.10) \\ \text { 1959Q2 } & 0.42(.00) & 15.80 & 0.65 & 18.94(.00) \\ \text { 1959Q4 } & 0.44(.00) & 10.81 & 0.39 & 13.57(.00) \\ \text { 1960Q2 } & 0.58(.00) & 12.12 & 0.44 & 21.09(.00) \\ \text { 1960Q4 } & 0.57(.00) & 14.12 & 0.46 & 17.26(.00) \\ \text { 1961Q2 } & 0.60(.00) & 15.86 & 0.50 & 16.98(.00) \\ \text { 1961Q4 } & 0.63(.00) & 17.49 & 0.37 & 21.17(.00)\end{array}$

Note: Estimates of equation (9). The test statistic is distributed as a $\chi^{2}$ with the p-value given in parenthesis. A positive number indicates that notional Canadian inflation is higher than US inflation. 


\section{References}

Aufricht, H. (1967), Central Banking Legislation, Vols. 1 and 2 (Washington, D.C.: International Monetary Fund).

Balke, N. and R. Gordon (1989), "The Estimation of Pre War Gross National Produce: Methodology and New Evidence”, Journal of Political Economy 97 (February): 38-92.

Bank of Canada (1958), Annual Report for the Year 1957. (Ottawa: Bank of Canada).

Bank of Canada (1959), Annual Report for the Year 1958. (Ottawa: Bank of Canada).

Bank of Canada (1960), Annual Report for the Year 1959. (Ottawa: Bank of Canada)

Bank of Canada (1961), Annual Report for the Year 1960. (Ottawa: Bank of Canada).

Bellan, R.C. (1961), “What Does Mr. Coyne Know About Money?” Winnipeg Free Press, 26 June.

Berlinguette, V.R. (1954), "Measurement of Real Output”, Canadian Journal of Economics and Political Science 20 (February): 59-75.

Binhammer, H.H. (1964), “Canada’s Foreign Exchange Problems: A Review”, Kyklos XVII: 636-53.

Blanchard, O., and D. Quah (1989), "The Dynamic Effects of Aggregate Demand and Supply Disturbance”, American Economic Review 79 (September): 655-73.

Bordo, M.D., A. Dib, and L. Schembri (2007), “Canada’s Pioneering Experience with Floating Exchange Rate in the 1950s: (Hard) Lessons Learned for a Monetary Policy in a Small Open Economy”, Bank of Canada working paper 2007-45.

Bremner, R.P. (2004), Chairman of the Fed: William McChesney Martin Jr. and the Creation of the American Financial System. (New Haven and London: Yale University Press).

Burdekin, R.C.K. and P.L. Siklos (1999), "Exchange Rate Regimes and Shifts in Inflation Persistence: Does Nothing Else Matter?” Journal of Money, Credit and Banking 31 (May): 23547.

Canadian Press (1961), “Coyne Reveals His Plan to Cut Jobless in Year”, Ottawa Journal, 19 June.

Cayen, J.-P. and S. van Norden (2005), “The Reliability of Canadian Output Gap Estimates”, North American Journal of Economics and Finance 16: 373-393.

Cameron, A.H. (1960), Letter to Donald Fleming, sent 19 October, Bank of Canada Archives. 
Christofides, L.N., J.F. Helliwell, and J.M. Lester (1976), “The Conversion Loan of 1958: A Simulation Study of Its Macroeconomic Consequences”, Canadian Journal of Economics 9 (August): 425-41.

Cornell, P. (1952-1955), “Exchange Rate Flexibility in Canada: Some Underlying Factors”, Bank of Canada Archives, LR 76-522 (1952-1955).

Coyne, J.E. (1961), Letter to Donald Fleming, Minister of Finance, 27 June, Bank of Canada Archives.

Coyne, J.E. (1961a), Speeches, Bank of Canada Archives file JEC 94-6, vol.2.

Coyne, J.E. (1949), “A Method of Combining a Free Exchange Rate with the Present System of Exchange Controls in Canada”, Bank of Canada memorandum, 31 January.

Deutsch, J. (1957), “The Canadian Treasury and Monetary Policy”, American Economic Review 47 (May): 220-28.

Freeman, G.E. (1959), “Canada’s Currency and Chartered Bank Deposits, 1926 to Date”, Bank of Canada Archives, Research 1B-620, vol.1, 15 December.

Goodfriend, M. (1998), "Interest Rate Policy and the Inflation Scare Problem: 1979-1992", Economic Quarterly, Federal Reserve Bank of Richmond 79 (Winter): 1-23.

Gordon, H.S. (1961), “The Bank of Canada in a System of Responsible Government”, Canadian Journal of Economics and Political Science 27 (February): 1-22.

Gordon, H.S. (1961a), The Economists Versus the Bank of Canada (Toronto: The Ryerson Press).

Gordon, H.S. and L.M. Read (1958), "The Political Economics of the Bank of Canada”, Canadian Journal of Economics and Political Science 24 (November): 465-82.

Jackson, R. (1960), “University Profs Demand Coyne Resign”, Ottawa Journal, 8 December.

Johnstone, R. (1958), “Exchange Rates and the Consumer Price Index”, Bank of Canada Archives file LR 76-522, 1956-1959.

Kozicki, S., and P.A. Tinsley (2007), "Perhaps the FOMC Did What it Said it Did: An Aleternative Interpretation of the Great Inflation”, Bank of Canada working paper 2007-19.

Knox, F.A. (1959), “A Statement” to the Standing Committee on Finance, The Senate of Canada, Bank of Canada Archives file LR 76-512. 
Kydland, F. and E. Prescott (1977), "Rules Rather Than Discretion: The Inconsistency of Optimal Plans”, Journal of Political Economy 85 (June): 473-92.

Mark, N.C. (2005), “Changing Monetary Policy Rules, Learning, and Real Exchange Rate Dynamics”, NBER working paper 11061, January.

McArthur, J. (1961), “Will Coyne’s Policies Help - or Hinder - Our Economy?” Toronto Daily Star, 16 January.

McChesney Martin, W. (1957), “Opening Statement”, at Panel Discussion on Current Problems in Monetary and Fiscal Policy, $12^{\text {th }}$ Annual Meeting of the International Bank for Reconstruction and Development and the International Monetary Fund, 25 September.

Metcalfe, A. Redish, R. Shearer (1998), "New Estimates of the Canadian Money Stock: 18711967”, Canadian Journal of Economics.

Mittra, S. (1977), Central Bank Versus Treasury: An International Study (Lanham, MD: University Press of America).

Moon, R. (1960), “High Marks for James Coyne”, Regina Leader-Post, 30 December.

Muirhead, B. (1999), The Public Life and Times of Louis Rasminsky (Toronto: University of Toronto Press).

Neufeld, E.P. (1958), “The Bank of Canada’s Approach to Central Banking”, Canadian Journal of Economics and Political Science 24 (August): 332-44.

Orphanides, A. (2001), “Monetary Policy Rules Based on Real-Time Data”, American Economic Review.

Pesando, J.E. (1975), "The Impact of the Conversion Loan on the Term Structure of Interest Rates in Canada: Some Additional Evidence”, Canadian Journal of Economics 8 (May): 281-88.

Phillips, A.W. (1958), “The Relation Between Unemployment and the Rate of Change in Money Wages in the United Kingdom, 1861-1957”, Economica (November).

Powell, J. (1999), A History of the Canadian Dollar (Ottawa: Bank of Canada).

Rasminsky, L.R. (1946-1951), “Letter from Minister of Finance to Graham Towers”, Bank of Canada Archives LR 76-522, 2 October 1950.

Shea, H. (1961), “Money Ills Fault of Government-Coyne”, Halifax Chronicle Herald, 16 June.

Siklos, P.L. (2008), “Canada's Experiment with a Floating Exchange Rates During the 1950s And Its Fear of Appreciation”, working paper, Wilfrid Laurier University. 
Siklos, P.L. (1999), “Inflation Target Design, Changing Inflation Performance and Persistence in Industrial Countries”, Review of the Federal Reserve Bank of St. Louis, 81 (March/April): 47-58.

Smith, D.C. and D.W. Slater (1961), “Easier Money Will Increase Jobs, Say These Two Queen’s Professors”, Financial Post, 25 February.

Smith, D.C. (1960), “Monetary-Fiscal Policy and Economic Growth in an Open Economy”, Quarterly Journal of Economics 74 (November): 614-32.

Timlin, M. (1953), "Recent Developments in Canadian Monetary Policy”, American Economic Review 43 (May): 42-53.

Yeager, L.B. (1976), International Monetary Relations: Theory, History and Policy, Second Edition, (New York: Harper and Row). 


\section{Appendix: Canadian Real Time Data, 1953-1969}

Data were collected from the National Accounts Income and Expenditures (NAIE) of the Dominion Bureau of Statistics (later renamed Statistics Canada). Beginning with the 1958Q3 issue, this publication was given the catalogue number 13-001. Some of the issues show an actual print date (e.g., 23-10-1953, that is, October 23, 1953) in the case of the issue for the first and second quarters of 1953. After 1954, the publication date is unclear. In all cases it was assumed that the data would have been made immediately available to the Bank of Canada to be used in the quarter following publication. Hence, a vintage dated 1953Q4 refers to data collected from the 1953Q3 edition of the NAIE. A total of 33 vintages of data were collected every two quarters beginning with the 1953Q4 edition of the NAIE. Although some observations go back to 1947, the earliest recorded figure used in the paper is for 1952Q1 in order to retain consistency throughout the vintages (subsequent issues of the NAIE only published data back to 1952Q1). Vintages of Gross National Expenditures at Market Prices (Table number changes across issues of the same publication) and were deflated by a quasi-final estimate of the implicit price index obtained from Cayen and van Norden (2005). 